\title{
GABAergic Influence in the Antidepressant Effect of Fluoxetine in Unstressed and Stressed Mice
}

\author{
Vaibhav Walia*, Neeraj Gilhotra \\ Division Pharmacology, Department of Pharmaceutical Sciences, Maharshi Dayanand University Rohtak-124001, Haryana, India.
}

\section{ARTICLE INFO \\ Article history: \\ Received on: 22/10/2016 \\ Accepted on: 11/12/2016 \\ Available online: $30 / 03 / 2017$}

Key words:

Depression, diazepam, GABA, immobilization, fluoxetine, mice, stress.

\begin{abstract}
Objective: To determine the influence of GABA in the antidepressant effect of fluoxetine in unstressed and stressed mice.

Materials and methods: Male swiss albino mice were used in the present study. Mice were stressed by immobilization for $2 \mathrm{~h}$. Mice subjected to immobilization were considered as stressed mice and mice not subjected to immobilization were considered as unstressed mice. Depression like behavioral alterations in unstressed and stressed mice was measured by tail suspension test (TST) followed by forced swim test (FST).

Results: The present study showed that the immobilization stress of $2 \mathrm{~h}$ significantly enhanced the immobility period of mice in both TST and FST. Fluoxetine (FLX) $(20 \mathrm{mg} / \mathrm{kg}$, i.p.) significantly reduced the immobility period of both unstressed and stressed mice significantly as compared to their respective controls. Diazepam (DZP) (2 and $4 \mathrm{mg} / \mathrm{kg}$, i.p.) significantly increased the immobility period of the unstressed mice whereas significantly reduced the immobility period of stressed mice in both TST and FST as compared to their respective controls. The combine treatment of DZP ( $2 \mathrm{mg} / \mathrm{kg}$, i.p. $)$ and FLX $(20 \mathrm{mg} / \mathrm{kg}$, i.p. $)$ to the unstressed mice reduced the immobility period of unstressed mice in both TST and FST significantly as compared to the vehicle and DZP ( $2 \mathrm{mg} / \mathrm{kg}$, i.p.) treated unstressed mice in TST. The co-administration of DZP ( $2 \mathrm{mg} / \mathrm{kg}$, i.p.) and FLX $(20 \mathrm{mg} / \mathrm{kg}$, i.p.) before the immobilization of $2 \mathrm{~h}$ significantly reduced the immobility period of stressed mice significantly as compared to the vehicle treated stressed mice in both TST and FST; whereas significantly as compared to the FLX $(20 \mathrm{mg} / \mathrm{kg}$, i.p.) treated stressed mice in TST only.

Conclusion: It has been concluded that the GABAergic influence is involved in the compromised antidepressant effect of the fluoxetine in stressed mice.
\end{abstract}

\section{INTRODUCTION}

Stress is a stimulus that disturbs the homeostasis of body and increases the vulnerability to mood disorders (Kendler et al., 1999; McEwen, 2003; Lupien et al., 2009). GABAergic transmission is highly sensitive to stressful situations (Orchinik et al., 2001; Caldji et al., 2004; Maggio and Segal, 2009; Surget et al., 2008); the fact is supported by the fact that the psychological stress induces presynaptic down-regulation of prefrontal GABAergic neurotransmission (Hasler et al., 2010).

* Corresponding Author

Vaibhav Walia, Division Pharmacology, Department of Pharmaceutical Sciences, Maharshi Dayanand University Rohtak-124001, Haryana, India.E-mail:vaibhav.walia00 @ gmail.com
GABA is the major inhibitory neurotransmitter present in the brain; synthesized by glutamic acid decarboxylase (GAD) (Chen et al., 2003). GABAergic dysfunction has been found to be responsible for depression because abnormally low cortical concentrations of GABA had been reported in the brains of depressed patients (Sanacora et al., 1999); also the concentrations of GABA had been found to be reduced in the plasma, cerebrospinal fluid (CSF), and cortex of depressed subjects (Sanacora et al., 2006).

The depressed subjects had significantly lower occipital cortex GABA concentrations compared with healthy controls (Sanacora et al., 2004). It has been reported that the chronic administration of antidepressant drugs induces marked changes in GABAergic function (Sanacora and Saricicek, 2007). 
For e.g. oral administration of fluoxetine $(5 \mathrm{mg} / \mathrm{kg})$ for 21 days elevated the CSF GABA levels by approximately 2-fold ( $\mathrm{P}<0.05)$ (Gören et al., 2007); also the chronic treatment with fluoxetine administered in drinking water normalizes GABA release in mice (Begenisic et al., 2014). SSRIs treatment known to increase the cortical GABA concentration in the depressed patients and therefore SSRIs act in part to restore the disrupted GABAergic activity (Licata et al., 2014).

$\mathrm{GABA}_{\mathrm{A}}$ receptor is the principal inhibitory neurotransmitter receptor in the mammalian brain (Kleingoor et al., 1993) and the altered expression or function of these receptors is increasingly implicated in the etiology of anxiety and depressive disorders (Merali et al., 2004; Sanacora et al., 2004; Bhagwagar et al., 2008; Poulter et al., 2008; Sequeira et al., 2009; Craddock et al., 2010; Klempan et al., 2009; Levinson et al., 2010).

$\mathrm{GABA}_{\mathrm{A}}$ receptor stimulation enhances the noradrenaline release in ventral NA pathway suggesting that the increasing GABAergic tone exerts antidepressant effect (Lloyd et al., Zivkovic, 1989). A possible role of $\mathrm{GABA}_{\mathrm{A}}$ receptor dysregulation in mood disorders has been controversial in part due to lack of a consensus about whether benzodiazepines (BZs) are therapeutically effective for the treatment of depression (Hasler et al., 2007). BZs, are the most widely prescribed psychotropic drugs, often used in the patients of depressive disorders, either alone or in combination with the standard antidepressants. BZs act as $\mathrm{GABA}_{\mathrm{A}}$ receptor agonists (Petty et al., 1995).

BZs act on $\mathrm{GABA}_{\mathrm{A}}$ receptors (Walters et al., 2000), but the binding of BZs agonist does not directly activate the $\mathrm{GABA}_{\mathrm{A}}$ receptor but potentiates the response to submaximal concentrations of GABA (Walters et al., 2000). Antidepressants with serotonergic effects known to enhance the function of the $\mathrm{GABA}_{\mathrm{A}}$ receptor (Matsubara et al., 2000) e.g. fluoxetine increase the brain and CSF content of allopregnanolone (Allo), a potent positive allosteric modulator of $\mathrm{GABA}_{\mathrm{A}}$ receptors (Pinna et al., 2006).

We previously reported that the antidepressant effect of fluoxetine gets attenuated in the stressed mice and the immobilization stress of $2 \mathrm{~h}$ compromised the antidepressant effect of fluoxetine in the stressed mice (Walia, 2016a). Also we reported previously that $2 \mathrm{~h}$ immobilization significantly increase the levels of the nitric oxide (NO) in the brain of mice (Walia and Gilhotra, 2016). NO is known to influence both the synthesis storage and release of 5-HT (Walia, 2016b; Sezal and Walia, 2015). Besides 5$\mathrm{HT}$, NO also influence the levels and the function of GABA, and the increase levels of NO has been found to be responsible for the downregulation of $\mathrm{GABA}_{\mathrm{A}}$ receptors (Gilhotra and Dhingra, 2011).

Thus it has been suggested that the stress induce NO release modulate the levels of 5-HT and GABA, that might be further responsible for altered antidepressant effect of the agents that modulate the levels and the neurotransmission of these neurotransmitters. Therefore the aim of the present study is to determine the possible GABAergic influence in the antidepressant activity of fluoxetine in stressed mice.

\section{MATERIALS AND METHODS}

\section{Animals}

Male swiss albino mice were used in the present study. All the mice were kept under controlled conditions of light and environmental and had free access to food and water. The testing was carried out between 9:00 and 16:00 h. The study protocols were approved by Institutional Animal Ethics Committee (IAEC) and care of the animals was carried out in compliance with the guidelines of the Committee for the Purpose of Control and Supervision of Experiments on Animals (CPCSEA) Ministry of Environment, Forests and Climate change, Government of India (Reg. No. 134/99/CPCSEA).

\section{Drugs and selection of doses}

Fluoxetine (FLX) (Cadila Pharmaceuticals, Ahmedabad, India) and Diazepam (DZP) (Neon Laboratories, Thane, India), were used in the present study. The doses were selected on the basis of the relevant previous studies. FLX (20 mg/kg; i.p.) was used as standard antidepressant drug (Walia, 2016a; Walia and Gilhotra, 2016) and DZP (2 mg/kg; i.p.), acts as a $\mathrm{GABA}_{\mathrm{A}}$ agonist and DZP (2 mg/kg; i.p.) has been found to increase the levels of the GABA in the brain of mice (Gilhotra and Dhingra, 2011).

\section{Immobilization stress}

Stress was produced by immobilizing the mice for $2 \mathrm{hrs}$ by taping, all its four limbs and trunk against a wooden board (Walia, 2016a; Walia and Gilhotra, 2016).

\section{Assessment of depression like behavior in mice Tail suspension test (TST)}

In TST, each mouse was individually suspended at a height of $30 \mathrm{~cm}$ from the floor, by adhesive tape placed approximately $1 \mathrm{~cm}$ from the tip of the tail. The immobility period was recorded for $6 \mathrm{~min}$. Mouse was considered to be immobile when it did not show any body movement, hung passively and completely immobile (Steru et al., 1985).

\section{Forced swim test (FST)}

In FST, each mouse was individually forced to swim in the open glass chamber containing fresh water to a height of $15 \mathrm{~cm}$ and maintained at $26 \pm 1^{\circ} \mathrm{C}$. Each mouse shows vigorous movements during the initial $2 \mathrm{~min}$ period of the test. The immobility period was recorded during the next 4 min of the total 6 min testing period (Porsolt et al., 1977).

\section{Experimental protocol}

Male swiss albino mice were used in the present study. Stress was produced by immobilizing the mice for $2 \mathrm{~h}$ (Walia, 2016a; Walia and Gilhotra, 2016). Mice subjected to stress were considered as stressed mice and mice not subjected to stress were 
considered as unstressed mice. All the treatments were administered intraperitoneally (i.p.) in fixed volume of $10 \mathrm{ml} / \mathrm{kg}$. Unstressed mice were administered $30 \mathrm{~min}$ prior to testing whereas the stressed mice were administered immediately before subjecting them to immobilization. In case of the pre-treatment or where the combinations of drugs were used, the time elapsed between the two treatments was $10 \mathrm{~min}$. Behavioral testing was started $10 \mathrm{~min}$ after setting the animal free from immobilization. Behavioral testing was performed in stepwise manner i.e. TST followed by FST with $5 \mathrm{~min}$ difference between the two testing procedures (Walia, 2016a; Walia and Gilhotra, 2016).

\section{Statistical analysis}

Data were analyzed by one-way analysis of variance (ANOVA) followed by Tukey's test. Values were expressed as Mean \pm S.E.M. and $\mathrm{p}<0.05$ was considered as statistically significant.

\section{RESULTS}

\section{Summary of the results}

\section{Effect of different treatment on the immobility period of mice in} TST and FST

The effect of different treatments on the immobility period of mice in both TST and FST was shown in the Fig. 1 and
Fig. 2. The present study showed that the immobilization stress of $2 \mathrm{~h}$ significantly enhanced the immobility period of mice as compared to the vehicle treated unstressed mice in both TST and FST. Thus it is suggested that $2 \mathrm{~h}$ immobilization stress significantly induced depression or enhances the depression in the mice subjected to immobilization of $2 \mathrm{~h}$. FLX (20 mg/kg, i.p.) significantly reduced the immobility period in both unstressed and stressed mice significantly as compared to their respective controls.

Administration of DZP ( 2 and $4 \mathrm{mg} / \mathrm{kg}$, i.p.) to the unstressed mice significantly increased the immobility period as compared to vehicle treated unstressed mice. However the administration of DZP ( 2 and $4 \mathrm{mg} / \mathrm{kg}$, i.p.) before subjecting the mice to the immobilization of $2 \mathrm{~h}$ significantly reduced the immobility period as compared to vehicle treated stressed mice in both TST and FST. The combine treatment of DZP ( $2 \mathrm{mg} / \mathrm{kg}$, i.p.) and FLX (20 $\mathrm{mg} / \mathrm{kg}$, i.p.) to the unstressed mice significantly reduced the immobility period as compared to the vehicle treated and DZP (2 $\mathrm{mg} / \mathrm{kg}$, i.p.) unstressed mice in TST and also significantly reduced the immobility period as compared to the FLX $(20 \mathrm{mg} / \mathrm{kg}$, i.p.) treated stressed mice in FST only. The co-administration of DZP ( $2 \mathrm{mg} / \mathrm{kg}$, i.p.) and FLX (20 mg/kg, i.p.) before the immobilization of $2 \mathrm{~h}$ significantly reduced the immobility period as compared to the vehicle treated stressed mice in both TST and FST; whereas compare to the FLX (20 mg/kg, i.p.) treated stressed mice in FST only.

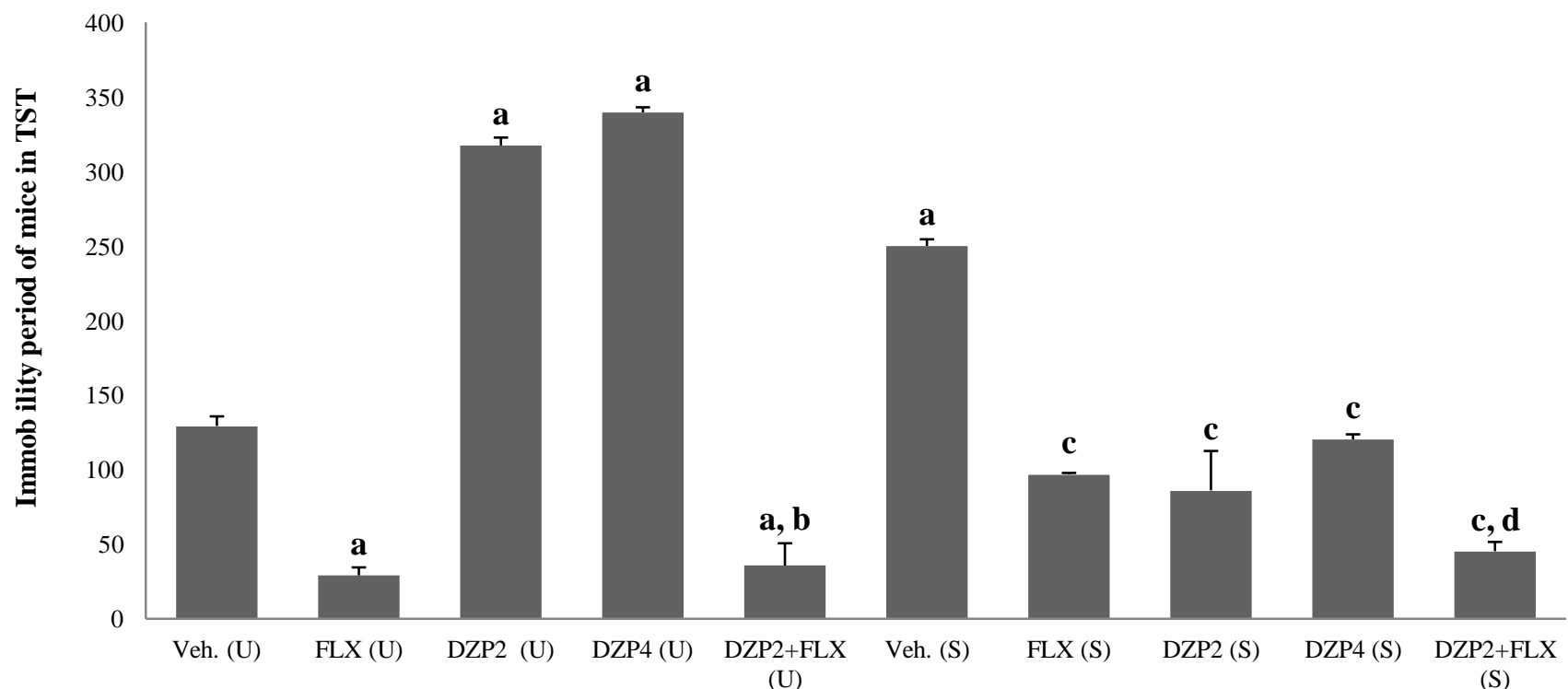

Fig.1. Effect of different treatments on immobility period of mice in TST. Values are expressed as mean \pm SEM, $n=5$ in each group. Data was analyzed by one way ANOVA followed by Tukey's Post hoc test, $\mathrm{F}(9,40)=121.98$. $\mathrm{a}=\mathrm{p}<0.001$ significant difference from the vehicle treated unstressed mice; $\mathrm{b}=\mathrm{p}<0.001$ significant difference from the DZP $(2 \mathrm{mg} / \mathrm{kg}$, i.p.) treated unstressed mice; $\mathrm{c}=\mathrm{p}<0.001$ significant difference from the vehicle treated stressed mice; $\mathrm{d}=\mathrm{p}<0.05$ significant difference from the FLX $(20 \mathrm{mg} / \mathrm{kg}$, i.p. $)$ treated stressed mice. Veh. (U): Vehicle treated unstressed mice; Veh. (S): Vehicle treated stressed mice; FLX (U): Fluoxetine (20 mg/kg, i.p.) treated unstressed mice; FLX (S): Fluoxetine (20 mg/kg, i.p.) treated stressed mice; DZP2 (U): Diazepam (2 mg/kg, i.p.) treated unstressed mice; DZP4 (U): Diazepam (4 mg/kg, i.p.) treated unstressed mice; DZP2 (S): Diazepam (2 mg/kg, i.p.) treated stressed mice; DZP4 (S): Diazepam (4 mg/kg, i.p.) treated stressed mice; DZP2 + FLX (U): Diazepam (2 mg/kg, i.p.) and fluoxetine (20 mg/kg, i.p.) treated unstressed mice; DZP2 + FLX (S): Diazepam (2 mg/kg, i.p.) and fluoxetine (20 mg/kg, i.p.) treated stressed mice. Doses were mentioned in $\mathrm{mg} / \mathrm{kg}$. 


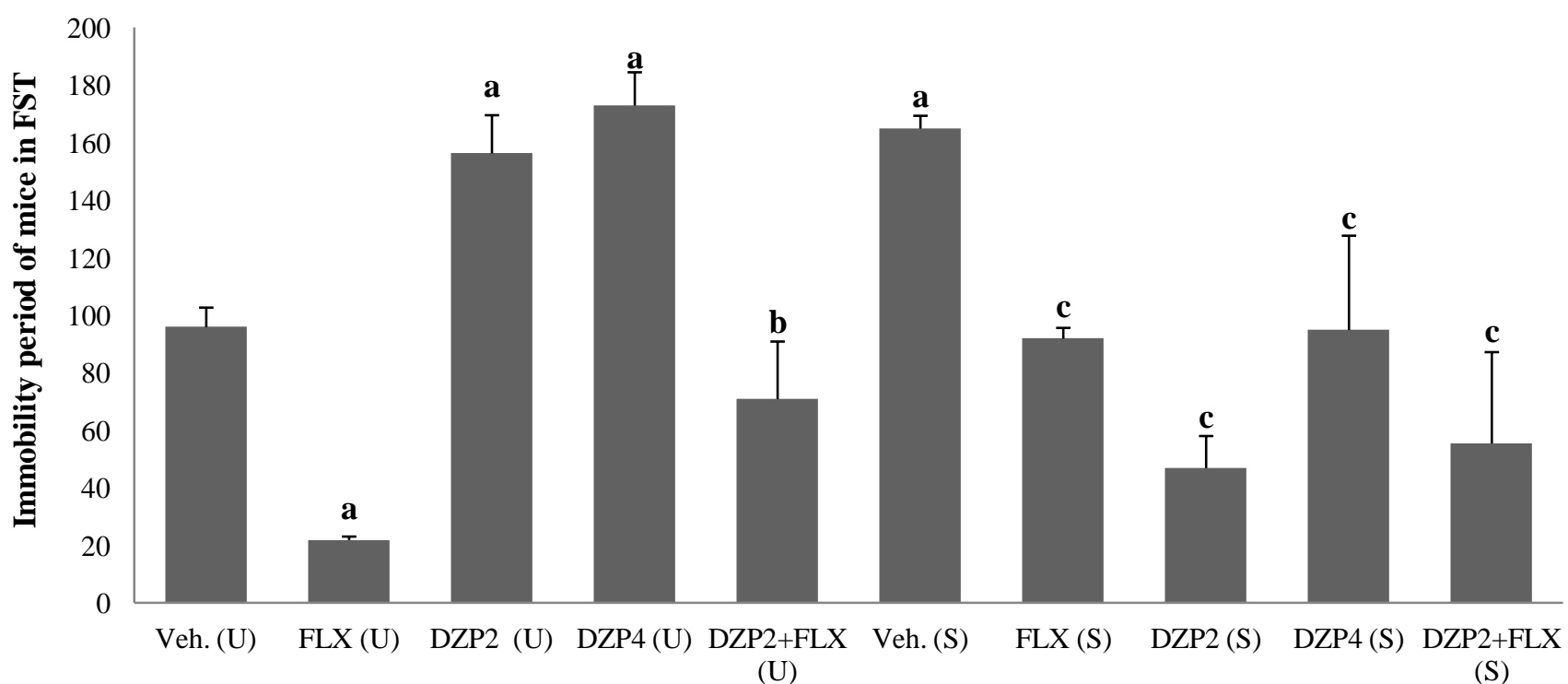

Fig.2. Effect of different treatments on immobility period of mice in FST. Values are expressed as mean \pm SEM, $\mathrm{n}=5$ in each group. Data was analyzed by one way ANOVA followed by Tukey's Post hoc test, $F(9,40)=34.355$. $a=p<0.001$ significant difference from the vehicle treated unstressed mice; $b=p<0.05$ significant difference from the FLX $(20 \mathrm{mg} / \mathrm{kg}$, i.p.) treated unstressed mice; $\mathrm{c}=\mathrm{p}<0.001$ significant difference from the vehicle treated stressed mice. Veh. (U): Vehicle treated unstressed mice; Veh. (S): Vehicle treated stressed mice; FLX (U): Fluoxetine ( $20 \mathrm{mg} / \mathrm{kg}$, i.p.) treated unstressed mice; FLX (S): Fluoxetine (20 $\mathrm{mg} / \mathrm{kg}$, i.p.) treated stressed mice; DZP2 (U): Diazepam (2 mg/kg, i.p.) treated unstressed mice; DZP4 (U): Diazepam (4 mg/kg, i.p.) treated unstressed mice; DZP2 (S): Diazepam (2 mg/kg, i.p.) treated stressed mice; DZP4 (S): Diazepam (4 mg/kg, i.p.) treated stressed mice; DZP2 + FLX (U): Diazepam (2 mg/kg, i.p.) and fluoxetine $(20 \mathrm{mg} / \mathrm{kg}$, i.p.) treated unstressed mice; DZP2 + FLX (S): Diazepam ( $2 \mathrm{mg} / \mathrm{kg}$, i.p.) and fluoxetine (20 mg/kg, i.p.) treated stressed mice. Doses were mentioned in $\mathrm{mg} / \mathrm{kg}$.

\section{DISCUSSION}

Stress induces depression like behavioral alteration in the laboratory animals subjected to the stress (Hyase, 2011). Depression like behavioral alteration in the laboratory animals can be measure by using TST and FST (Porsolt et al., 1977; Steru et al., 1985). In the present study we used TST followed by FST; the main reason behind is to reduce the use of number of animals. However we used TST followed by FST because after FST the mice wets completely and therefore cannot be used immediately in the TST. Also FST is a more stressful procedure than TST. FST is known to produce the hypothermia in the mice or the animals subjected to the FST. Therefore to avoid such problems we used TST followed by FST in the present study.

Depression like behavioral alteration can be produced by the stressors such as immobilization stress (Hyase, 2011). The results of the present study showed that the immobilization stress enhanced the immobility period of the mice in both TST and FST significantly as compared to the vehicle treated unstressed mice. Also the immobilization stress of $2 \mathrm{~h}$ has been shown to increase the immobility period of the mice in the various previous studies (Walia, 2016; Walia and Gilhotra, 2016). GABAergic transmission is highly sensitive to stressful situations (Orchinik et al., 2001; Caldji et al., 2004; Maggio and Segal, 2009; Surget et al., 2008). Also the altered levels of GABA had been reported in the patients of depression (Gold et al, 1980; Price et al., 2009). Further the network dysfunction in association with altered brain levels of glutamate and GABA have been identified in both animal and human studies of depression (Lener et al., 2016). Thus the dysfunction of the GABAergic system is associated with major depression (Sanacora et al., 1999) and therefore the treatment with the GABAergic agents or GABA modulating drugs may exerts the beneficial effects (Birkenhäger et al., 1995). For example in one study alprazolam has been shown to reduce the anhedonia (Petty et al., 1995). In the present study the administration of fluoxetine (20 $\mathrm{mg} / \mathrm{kg}$; i.p.) reduced the immobility period of unstressed and stressed mice in both TST and FST significantly as compared to their respective controls. Also the immobility period of fluoxetine (20 $\mathrm{mg} / \mathrm{kg}$; i.p.) treated stressed mice was greater than the fluoxetine $(20 \mathrm{mg} / \mathrm{kg}$; i.p.) treated unstressed mice in both TST and FST. Thus the antidepressant effect of the fluoxetine (20 $\mathrm{mg} / \mathrm{kg}$; i.p.) was compromised by the immobilization stress of $2 \mathrm{~h}$. Fluoxetine (Prozac), is an antidepressant drug that selectively inhibit the reuptake of 5-HT and is widely used in the treatment of the mood disorders (Caiati and Cherubini, 2013). Fluoxetine was ineffective in changing the CSF GABA levels at the dose of 2.5 $\mathrm{mg} / \mathrm{kg}$ but produced a significant increase in the perfusates following injection of $5 \mathrm{mg} / \mathrm{kg}$ of fluoxetine. Also the oral fluoxetine administration $(5 \mathrm{mg} / \mathrm{kg}$ ) for 21 days also elevated the CSF GABA levels by approximately 2-fold (Goren et al., 2007). Robinson et al show that fluoxetine acts as a positive allosteric modulator on $\mathrm{GABA}_{\mathrm{A}}$-receptor (Robinson et al., 2003). Low fluoxetine concentrations ( $1 \mathrm{nM})$ enhanced GABA-stimulated $\mathrm{Cl}$ uptake by a rat cerebral cortical vesicular preparation whereas the higher concentrations (100 microM and $1 \mathrm{mM})$, inhibited GABAstimulated $\mathrm{Cl}^{-}$uptake (Tunnicliff et al., 1999). Chronic fluoxetine 
can increase the intrinsic excitability in some interneurons (Zhong and Yan, 2011) and increase CSF GABA concentrations (Gören et al., 2007) while at the same time reducing 5-HT effect on phasic GABA activation (Zhong and Yan, 2004; Zhong and Yan, 2011) it is unclear whether fluoxetine's GABA-enhancing effects are beneficial for mood. Antidepressants with serotonergic effects enhanced the function of $\mathrm{GABA}_{\mathrm{A}}$ receptor complex (Matsubara et al., 2000). SSRIs cause an acute increase in brain GABA levels (Bhagwagar et al., 2004; Sanacora et al., 2002). SSRI treatment has a slight influence on GABAergic transmission in the hippocampus (Choi et al., 2010). SSRIs treatment increases the cortical GABA levels in the depressed patients and suggest that this results from an action of SSRIs on GABA neurons rather than as a secondary consequence of mood improvement (Bhagwagar et al., 2004). SSRIs thus act in part to restore the disrupted GABAergic activity (Licata et al., 2014). Preclinical studies demonstrate that GABA modulating agents are active in commonly used rodent behavioral models of antidepressant activity, and that chronic administration of antidepressant drugs induces marked changes in GABAergic function (Sanacora and Saricicek, 2007).

If the GABAergic dysfunction contributes to depression therefore the agents that increase the levels of the GABA might exerts the antidepressants like effect. To determine the possible GABAergic influence in the compromised antidepressant effect of fluoxetine (20 mg/kg; i.p.) in stressed mice; we administered diazepam in unstressed and stressed mice alone and in combination with the fluoxetine to determine the possible beneficial outcomes. Administration of DZP ( 2 and $4 \mathrm{mg} / \mathrm{kg}$; i.p.) in unstressed mice enhanced the immobility period of unstressed mice in a dose dependent manner in both TST and FST significantly as compared to the vehicle treated unstressed mice as shown in fig. 1 and 2. However the administration of DZP (2 and 4 $\mathrm{mg} / \mathrm{kg}$; i.p.) in stressed mice reduced the immobility period of stressed mice in both TST and FST significantly as compared to the vehicle treated stressed mice as shown in fig.1 and 2.. However the immobility period of the stressed mice treated with DZP (4 $\mathrm{mg} / \mathrm{kg}$; i.p.) was greater than the immobility period of the stressed mice treated with DZP (2 mg/kg; i.p.). Diazepam belongs to the category of BZs, widely used clinically for relief of anxiety and for sedation (Eghbali et al., 1997). Diazepam acts as the positive allosteric modulator of $\mathrm{GABA}_{\mathrm{A}}$ receptor; upon binding $\mathrm{GABA}_{\mathrm{A}}$ complex undergoes a conformational change, resulting in increased affinity of the receptor for the endogenous GABA ligand and this results in the increase in the neuronal chloride-ion influx resulting in the hyperpolarization of the postsynaptic membranes (Nutt and Malizia, 2001). The hyperpolarization further result in the subsequent inhibition of the firing threshold and result is CNS depression (Nutt and Malizia, 2001; Battistin et al., 1984; Sieghart, 1995). Diazepam enhances the binding of GABA to its receptors (Skerritt and Macdonald, 1984). Also the diazepam increased the frequency of GABA receptor currents with minimal effect on the duration of bursts (Twyman et al., 1989). Stress evokes the release of glutamate in the brain that results in the activation of NMDA receptors responsible for excitotoxicity (Maj et al., 1992) and the diazepam through its GABA facilitatory action may exerts the antidepressant effect. This might be the possible reason why diazepam reduced the immobility period of stressed mice. Co-administration of BZs with SSRIs can lead to significantly greater treatment response, as well as faster onset of efficacy (Fava et al., 2006; Fava et al., 2011). In the present study, administration of DZP (2 mg/kg; i.p.) followed by the administration of fluoxetine $(20 \mathrm{mg} / \mathrm{kg}$; i.p.) in unstressed mice increased the immobility period of the mice in both TST and FST significantly as compared to fluoxetine $(20 \mathrm{mg} / \mathrm{kg}$; i.p. $)$ treated unstressed mice. However the administration of DZP $(2 \mathrm{mg} / \mathrm{kg}$; i.p.) followed by the administration of fluoxetine $(20 \mathrm{mg} / \mathrm{kg}$; i.p.) in stressed mice reduced the immobility period of mice in both TST and FST significantly as compared to vehicle treated stressed mice. Administration of DZP (2 mg/kg; i.p.) followed by the administration of fluoxetine $(20 \mathrm{mg} / \mathrm{kg}$; i.p.) in stressed mice reduced the immobility period of mice in TST significantly as compared to the fluoxetine $(20 \mathrm{mg} / \mathrm{kg}$; i.p.) treated stressed mice. It has been reported that the adult outpatients treated with fluoxetine $20 \mathrm{mg}$ + clonazepam $0.5-1.0 \mathrm{mg}$ accelerated the response of treatment, decreasing anxiety, sleep disturbances and suppressed the SSRIs side-effects (Londborg et al., 2000). Extended clonazepam cotherapy of fluoxetine appeared safe and effective for depressed outpatients: it was superior to fluoxetine alone early in treatment and again following fluoxetine dose increase. Cotherapy might be considered at the start of fluoxetine treatment, especially for those with insomnia, and when a dose increase of fluoxetine is anticipated (Smith et al., 2002). SSRIs are reported to increase the risk of the suicidality (Walia, 2016c) and the main reason behind this is the development of the akathisia; that occurs frequently with the SSRIs treatment (Healy et al., 2006) and it may be one of the main causes of suicidality associate with the SSRIs therapy (Rothschild and Locke, 1991). Therefore to minimize the incidence of akathisisa, agitation and anxiety, benzodiazepines had been co-prescribed with SSRIs (Healy, 1999).

\section{CONCLUSION}

It is concluded that stress is mainly responsible for the induction of psychiatric disorders such as depression. BZs are effective in the treatment of stress induced psychiatric disorders such as anxiety and depression. Both SSRIs and BZs have been found to increase the levels of GABA in the brain. However the use of BZs led to decline in attention/concentration, problem solving skills, general intelligence, psychomotor speed, memory etc. SSRIs are effective in the treatment of stress induced psychiatric disorders but the use of the SSRIs increased the risk of suicidality in the prescribed patients. SSRIs induced akathisia is mainly responsible for the emergence of suicidality. Therefore SSRIs are often co-prescribed with BZs. Also the present study showed the superiority of combine treatment of BZ and SSRI as compared to SSRI alone. 
Funding Source: None

Conflict of Interests: There are no conflicts of interest.

\section{REFERENCES}

Anki, Walia V. Influence of Gender Difference in the Antidepressant effect of Fluoxetine in Mice in Tail Suspension Test. Asian J Pharm Clin Res. 2017; 10(1): 230-233.

Battistin L, Varotto M, Berlese G, Roman G. Effects of Some Anticonvulsant Drugs on Brain Gaba Level and Gad and Gaba-T Activities. Neurochem Res. 1984; 9(2): 225-31.

Begenisic T, Baroncelli L, Sansevero G, Milanese M, Bonifacino T, Bonanno G, Cioni G, Maffei L, Sale A. Fluoxetine in adulthood normalizes GABA release and rescues hippocampal synaptic plasticity and spatial memory in a mouse model of Down syndrome. Neurobiol Dis. 2014; 63: 12-9.

Bhagwagar Z, Wylezinska M, Jezzard P, Evans J, Boorman E, Matthews PM, et al. Low GABA concentrations in occipital cortex and anterior cingulate cortex in medication-free, recovered depressed patients. Int J Neuropsychopharmacol. 2008; 11: 255-260.

Bhagwagar Z, Wylezinska M, Taylor M, Jezzard P, Matthews PM, Cowen PJ. Increased brain GABA concentrations following acute administration of a selective serotonin reuptake inhibitor. Am J Psychiatry. 2004;161(2): 368-70.

Birkenhäger TK, Moleman P, Nolen WA. Benzodiazepines for depression? A review of the literature. Int Clin Psychopharmacol. 1995; 10(3): 181-95.

Caiati MD, Cherubini E. Fluoxetine impairs GABAergic signaling in hippocampal slices from neonatal rats. Front Cell Neurosci. 2013; 7: 63.

Caldji C, Diorio J, Anisman H, Meaney MJ. Maternal behavior regulates benzodiazepine/ $\mathrm{GABA}_{\mathrm{A}}$ receptor subunit expression in brain regions associated with fear in $\mathrm{BALB} / \mathrm{c}$ and $\mathrm{C} 57 \mathrm{BL} / 6$ mice. Neuropsychopharmacol. 2004; 29: 1344-52.

Chen C-H, Battahlioli G, Martin DL, Hobart SA, Colon W. Distinctive interactions in the holoenzyme formation for two isoforms of glutamate decarboxylase. Biochim Biophys Acta. 2003; 1645: 63-71

Choi HC, Kim YI, Song HK, Kim JE, Kim DS, Kang TC. Effects of selective serotonin reuptake inhibitors on GABAergic inhibition in the hippocampus of normal and pilocarpine induced epileptic rats. Brain Res. 2010; 1357: 131-41.

Craddock N, Jones L, Jones IR, Kirov G, Green EK, Grozeva D, Moskvina V, Nikolov I, Hamshere ML, Vukcevic D, Caesar S, Gordon-Smith K,Fraser C, Russell E, Norton N, Breen G, St Clair D, Collier DA, Young AH, Ferrier IN, Farmer A, McGuffin P, Holmans PA; Wellcome Trust Case Control Consortium (WTCCC), Donnelly $\mathrm{P}$, Owen MJ, O'Donovan MC. Strong genetic evidence for a selective influence of $\mathrm{GABA}(\mathrm{A})$ receptors on a component of the bipolar disorder phenotype. Mol Psychiatry. 2010; 15: 146-53.

Eghbali M, Curmi JP, Birnir B, Gage PW. Hippocampal GABA(A) channel conductance increased by diazepam. Nature. 1997; 388(6637): 71-5.

Fava M, McCall WV, Krystal A, Wessel T, Rubens R, Caron J, Amato D, Roth T. Eszopiclone co-administered with fluoxetine in patients with insomnia coexisting with major depressive disorder. Biol Psychiatry.2006; 59(11): 1052-60.

Fava M, Schaefer K, Huang H, Wilson A, Iosifescu DV, Mischoulon D, Wessel TC. A post hoc analysis of the effect of nightly administration of eszopiclone and a selective serotonin reuptake inhibitor in patients with insomnia and anxious depression. J Clin Psychiatry. 2011; 72(4): 473-9.

Gilhotra N, Dhingra D. Thymoquinone produced antianxietylike effects in mice through modulation of GABA and NO levels. Pharmacol Rep. 2011; 63(3): 660-9.

Gold BI, Bowers MB, Jr, Roth RH, Sweeney DW. GABA levels in CSF of patients with psychiatric disorders. Am J Psychiatry. 1980; 137(3): 362-64.
Gören MZ, Küçükibrahimoglu E, Berkman K, Terzioglu B. Fluoxetine partly exerts its actions through GABA: a neurochemical evidence. Neurochem Res. 2007; 32(9): 1559-65.

Hasler G, van der Veen JW, Grillon C. Effect of acute psychological stress on prefrontal gamma-aminobutyric acid concentration determined by proton magnetic resonance spectroscopy. Am J Psychiatry. 2010; 167(10): 1226-31.

Healy D, Herxheimer A, Menkes DB. Antidepressants and Violence, Problems at the Interface of Medicine and Law. PLoS Med. 2006; 3(9), e372.

Healy D, Langmaak, C, Savage M. Suicide in the course of the treatment of depression. J. Psychopharmacol. 1999; 13: 94-9.

Hyase T. Depression- related anhedonic behaviors caused by the immobilization stress: a comparison with nicotine -induced depression like behavioral alterations and effects of nicotine and / or "antidepressant" drugs. J Toxicol Sci. 2011; 36(1): 31-41.

Kendler KS, Karkowski LM, Prescott CA. Causal relationship between stressful life events and the onset of major depression. Am J Psychiatry. 1999; 156: 837-41.

Kleingoor C, Wieland HA, Korpi ER, Seeburg PH, Kettenmann H. Current potentiation by diazepam but not GABA sensitivity is determined by a single histidine residue. Neuroreport. 1993; 4(2): 18790.

Klempan TA, Sequeira A, Canetti L, Lalovic A, Ernst $\mathrm{C}$, ffrench-Mullen J, Turecki G. Altered expression of genes involved in ATP biosynthesis and GABAergic neurotransmission in the ventral prefrontal cortex of suicides with and without major depression. Mol Psychiatry. 2009; 14: 175-89.

Lener MS, Niciu MJ, Ballard ED, Park M, Park LT, Nugent AC, Zarate CA Jr. Glutamate and Gamma-Aminobutyric Acid Systems in the Pathophysiology of Major Depression and Antidepressant Response to Ketamine. Biol Psychiatry. 2016 May 12. pii: S0006-3223(16)32377-0.

Levinson AJ, Fitzgerald PB, Favalli G, Blumberger DM, Daigle M, Daskalakis ZJ. Evidence of cortical inhibitory deficits in major depressive disorder. Biol Psychiatry. 2010; 67: 458-64.

Licata SC, Jensen JE, Conn NA, Winer JP, Lukas SE. Zolpidem increases GABA in depressed volunteers maintained on SSRIs. Psychiatry Res. 2014; 224(1): 28-33.

Lloyd KG, Zivkovic B, Scatton B, Morselli PL, Bartholini G. The gabaergic hypothesis of depression. Prog Neuropsychopharmacol Biol Psychiatry. 1989; 13(3-4): 341-51.

Londborg PD, Smith WT, Glaudin V, Painter JR. Short-term cotherapy with clonazepam and fluoxetine: anxiety, sleep disturbance and core symptoms of depression. J Affect Disord. 2000; 61(1-2): 73-9.

Lupien SJ, McEwen BS, Gunnar MR, Heim C. Effects of stress throughout the lifespan on the brain, behaviour and cognition. Nat Rev Neurosci. 2009; 10: 434-45.

Maggio N, Segal M. Differential corticosteroid modulation of inhibitory synaptic currents in the dorsal and ventral hippocampus. J Neurosci. 2009; 29: 2857-66.

Maj J, Rogoz Z, Skuza G, Sowińska H. The effect of CGP37849 and CGP 39551, competitive NMDA receptor antagonists, in the forced swimming test. Pol J Pharmacol. 1992; 44: 337-46.

Matsubara M, Suzuki S, Miura K, Terashima M, Sugita S, Kimura H, Hatsuda S, Mori T, Murakami H, Hayashi T, Ohta T, Ohara M. Electrophysiologic analysis of antidepressant drug effects on the GABA(A) receptor complex based upon antagonist-induced encephalographic power spectrum changes. Neuropsychobiol. 2000; 42(3): 149-57.

McEwen BS. Early life influences on life-long patterns of behavior and health. Ment Retard Dev Disabil Res Rev. 2003; 9: 14954.

Merali Z, Du L, Hrdina P, Palkovits M, Faludi G, Poulter MO, Anisman H. Dysregulation in the suicide brain: mRNA expression of corticotropin-releasing hormone receptors and $\mathrm{GABA}(\mathrm{A})$ receptor subunits in frontal cortical brain region. J Neurosci. 2004; 24: 1478-85.

Nutt DJ, Malizia AL. New insights into the role of the GABA(A)-benzodiazepine receptor in psychiatric disorder. Br. J. Psychiatry 2001; 179(5), 390-6. 
Orchinik M, Carroll SS, Li YH, McEwen BS, Weiland NG. Heterogeneity of hippocampal $\operatorname{GABA}(\mathrm{A})$ receptors: regulation by corticosterone. J Neurosci. 2001; 21: 330-9.

Petty F, Trivedi MH, Fulton M, Rush AJ. Benzodiazepines as antidepressants: does GABA play a role in depression? Biol Psychiatry. 1995; 38(9): 578-91.

Pinna G, Costa E, Guidotti A. Fluoxetine and norfluoxetine stereospecifically and selectively increase brain neurosteroid content at doses that are inactive on 5-HT reuptake. Psychopharmacol (Berl). 2006; 186(3): 362-72.

Porsolt RD, Bertin A, Jalfre M. Behavioural despair in mice: a primary screening test for antidepressants. Arch Int Pharmacodyn Ther. 1977; 229: 327-36.

Poulter MO, Du L, Weaver IC, Palkovits M, Faludi G, Merali Z, Szyf M, Anisman H. GABAA receptor promoter hypermethylation in suicide brain: implications for the involvement of epigenetic processes. Biol Psychiatry. 2008; 64: 645-52.

Price RB, Shungu DC, Mao X, Nestadt P, Kelly C, Collins KA, Murrough JW, Charney DS, Mathew SJ. Amino acid neurotransmitters assessed by proton magnetic resonance spectroscopy: relationship to treatment resistance in major depressive disorder. Biol Psychiatry. 2009; 65(9): 792-800.

Robinson RT, Drafts BC, Fisher JL. Fluoxetine increases GABA(A) receptor activity through a novel modulatory site. J Pharmacol Exp Ther. 2003; 304(3): 978-84.

Rothschild AJ, Locke CA. Reexposure to fluoxetine after serious suicide attempts by three patients, the role of akathisia. J Clin Psychiatry. 1991; 52, 491-3.

Sanacora G, Mason GF, Rothman DL, Krystal JH. Increased occipital cortex GABA concentrations in depressed patients after therapy with selective serotonin reuptake inhibitors. Am J Psychiatry. 2002; 159(4): 663-5.

Sanacora G, Fenton LR, Fasula MK, Rothman DL, Levin Y, Krystal JH, Mason GF. Cortical gamma-aminobutyric acid concentrations in depressed patients receiving cognitive behavioral therapy. Biol Psychiatry. 2006; 59(3): 284-6.

Sanacora G, Gueorguieva R, Epperson CN, Wu YT, Appel M, Rothman DL, Krystal JH, Mason GF. Subtype-specific alterations of gamma-aminobutyric acid and glutamate in patients with major depression. Arch Gen Psychiatry. 2004; 61: 705-13.

Sanacora G, Mason GF, Rothman DL, Behar KL, Hyder F, Petroff OA, Berman RM, Charney DS, Krystal JH. Reduced cortical gamma-aminobutyric acid levels in depressed patients determined by proton magnetic resonance spectroscopy. Arch Gen Psychiatry. 1999; 56(11): 1043-7.

Sanacora G, Saricicek A. GABAergic contributions to the pathophysiology of depression and the mechanism of antidepressant action. CNS Neurol Disord Drug Targets. 2007; 6(2): 127-40.

Sequeira A, Mamdani F, Ernst C, Vawter MP, Bunney WE, Lebel V, Rehal S, Klempan T, Gratton A, Benkelfat C, Rouleau GA, Mechawar N, Turecki G. Global brain gene expression analysis links glutamatergic and GABAergic alterations to suicide and major depression. PLoS One. 2009; 4: e6585.

Sezal, Walia V. Review: Tinospora cordifolia in the treatment of depression. Pharmatutor 2015; 3(12): 32-34.
Sieghart W. Structure and Pharmacology of GammaAminobutyric Acid(a) Receptor Subtypes. Pharmacol. Rev. 1995; 47(2): 181-234.

Skerritt JH, Macdonald RL. Diazepam enhances the action but not the binding of the GABA analog, THIP. Brain Res. 1984; 297(1): 1816

Smith WT, Londborg PD, Glaudin V, Painter JR; Summit Research Network. Is extended clonazepam cotherapy of fluoxetine effective for outpatients with major depression? J Affect Disord. 2002; 70(3): 251-9.

Steru L, Chermat R, Thierry B, Simon P. The tail suspension test: a new method for screening antidepressants in mice. Psychopharmacol (Berl). 1985; 85: 367.

Surget A, Wang Y, Leman S, Ibarguen-Vargas Y, Edgar N, Griebel G, Belzung C, Sibille E. Corticolimbic transcriptome changes are state-dependent and region-specific in a rodent model of depression and of antidepressant reversal. Neuropsychopharmacol. 2008; 34: 1363 80

Tunnicliff G, Schindler NL, Crites GJ, Goldenberg R, Yochum A, Malatynska E. The $\operatorname{GABA}(\mathrm{A})$ receptor complex as a target for fluoxetine action. Neurochem Res. 1999; 24(10): 1271-6.

Twyman RE, Rogers CJ, Macdonald RL. Differential regulation of gamma-aminobutyric acid receptor channels by diazepam and phenobarbital. Ann Neurol. 1989; 25(3): 213-20.

Walia V, Gilhotra N. Nitriergic Influence in the Compromised Antidepressant Effect of Fluoxetine in Stressed Mice. J App Pharm Sci 2016 (Article in Press).

Walia V. Influence of stress and fluoxetine on immobility period of mice in tail suspension test and forced swim test. Asian J Pharm Clin Res. 2016a; 9(2): 1-4.

Walia V. Possible Role of Serotonin and Selective Serotonin Reuptake Inhibitors in Suicidal Ideations and Attempts. J Pharm Sci Pharmacol 2016c (Article in Press).

Walia V. Role of enzymes in the pathogenesis of depression. J Crit Rev. 2016b; 3(2): 1-6.

Walters RJ, Hadley SH, Morris KD, Amin J. Benzodiazepines act on GABAA receptors via two distinct and separable mechanisms. Nat Neurosci. 2000; 3(12): 1274-81.

Zhong P, Yan Z. Chronic antidepressant treatment alters serotonergic regulation of GABA transmission in prefrontal cortical pyramidal neurons. Neuroscience. 2004; 129(1): 65-73.

Zhong P, Yan Z. Differential regulation of the excitability of prefrontal cortical fast-spiking interneurons and pyramidal neurons by serotonin and fluoxetine. PloS One. 2011; 6(2): e16970.

\section{How to cite this article:}

Walia V, Gilhotra N. GABAergic Influence in the Antidepressant Effect of Fluoxetine in Unstressed and Stressed Mice. J App Pharm Sci, 2017; 7 (03): 141-147. 